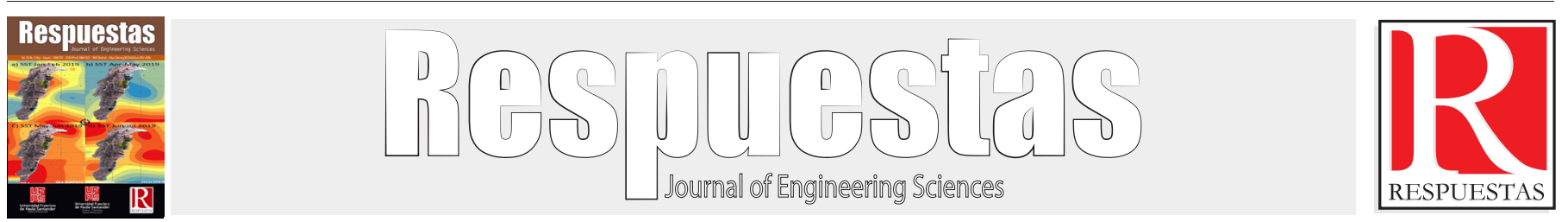

Original Article

https://doi.org/10.22463/0122820X.2562

\title{
Induction motor sensorless control by DSP
}

Control sensorless del motor de inducción mediante DSP

Edison Andrés Caicedo-Peñaranda ${ }^{1}$, Henry Alfonso Sepúlveda-Pacagui ${ }^{2}$, Luis David Pabón Fernández ${ }^{3}$, Aldo Pardo-García ${ }^{4 *}$, Jorge Luis Díaz-Rodríguez ${ }^{5}$

${ }^{1}$ Magister controles industriales, eacaicedop@gmail.com, Orcid: 0000-0003-4557-1061, Universidad de Pamplona, Pamplona, Colombia.

2Ingeniero eléctrico, sepu08@hotmail.com, Orcid: 0000-0002-1845-6503, Universidad de Pamplona, Pamplona, Colombia.

${ }^{3}$ Magister controles industriales, davidpabon@hotmail.es, Orcid: 0000-0003-1788-4781, Universidad de Pamplona, Pamplona, Colombia.

4*Posdoctor en ingeniería eléctrica, apardo13@hotmail.com, Orcid: 0000-0003-2040-9420, Universidad de Pamplona, Pamplona, Colombia.

${ }^{5}$ Maestría en automática, jdiazcu@gmail.com, Orcid: 0000-0001-7661-8665, Universidad de Pamplona, Pamplona, Colombia.

How to cite: E.A. Caicedo-Peñaranda, H.A. Sepúlveda-Pacagui, L.D. Pabón Fernández, A. Pardo-García, J.L. Díaz-Rodríguez “Induction motor sensorless control by DSP". Respuestas, vol. 25, no. 2, 6-15.

Received: February 07, 2020; Approved: April 5, 2020

\begin{tabular}{ll}
\hline & ABSRACT \\
\hline Keywords: & This paper deals with the development of an algorithm for speed control of the induction motor by \\
& means of the DSP core microcontroller TMS320F28069M, which perform a digital treatment of \\
Frequency converter, control & the voltage and electrical current signals measured to estimate the rotor speed and close the control \\
V/F, PWM. & loop. The algorithms consider the operating limits and the characteristics of the DSP, together \\
& with an interface that allows monitoring the estimated speed, and modifying the operating point \\
& and the constants of the PI controller, the controller output is assigned to an output of the DSP \\
& PWM_DAC which is connected to an ABB ACS800-U1 frequency converter in remote mode to \\
& carry out the motor speed change by means of a V / F control law.
\end{tabular}

\begin{tabular}{ll}
\hline \hline & RESUMEN \\
\hline Palabras Clave: & Este artículo presenta el desarrollo un algoritmo para el control de velocidad del motor de inducción \\
Convertidor de frecuencia, & mediante el microcontrolador con núcleo de DSP TMS320F28069M, el cual realiza el tratamiento digital \\
control V/F, PWM. & de las señales de voltaje y corriente medidas para estimar la velocidad del rotor y cerrar el lazo de control. \\
& Los algoritmos consideran los límites de operación y las características del DSP, en conjunto con una \\
& interfaz que permite monitorear la velocidad estimada, y modificar el punto de operación y las constantes \\
& del controlador PI, la salida del controlador es asignada a una salida del DSP PWM_DAC la cual se \\
& conecta a un convertidor de frecuencia ABB ACS800-U1 en modo remoto para realizar el cambio de \\
& velocidad del motor mediante una ley de control V/F.
\end{tabular}

\section{Introduction}

The microcontrollers such as the family тм C2000 [1], become widespread when the technology matures its manufacture. Also when the characteristics of the applications are needed to efficiently solve the tasks of digital signal processing. Usually, requiring reinforced architectures and extension of the instructions repertoire of the MCU types as DSP's.

The induction motors are frequently used in industrial applications [2] for its simplicity, reliability, and low cost. Accompanied by the advances in power electronics, control algorithms, and the development of embedded systems capable of applying control techniques with optimum performance in energy efficiency, accuracy, and control quality [3].

Our research aims to develop a speed control using a frequency converter in remote mode, acting as the final control element. Whereas the sensorless control technique incorporated an embedded system [4], using this control technique programmed in the DSP TMS320F28069M. Great advantages can be obtained in terms of input data processing since each data must be transformed according to complex formulas. This can be

*Corresponding author.

E-mail Address:apardo13@hotmail.com (Aldo Pardo-García)

(c) (i) $\ominus$ Peer review is the responsibility of the Universidad Francisco de Paula Santander. 
achieved since they are designed for high-performance repetitive and numerically intense tasks, the high speeds that these devices provide an efficient way of processing data [5].

\section{Materials and methods}

\section{TMS320F28069 and control methodology}

LAUNCHXL-28069M: It is a complete low-cost development board for Texas Instruments Piccolo F2806x devices [6]. The selected LAUNCHXL-28069M kit presents high efficiency of hardware and software needed to develop applications in motor control where development can be evaluated at academic or research level [7].

The board performs data acquisition for further processing, which makes it possible to estimate the motor speed for the implementation of the control loop [8]. The low-cost 32-bit Piccolo ${ }^{\mathrm{TM}}$ TMS320F28069 microcontroller from Texas Instruments offers a solution to control the speed of a motor from the sensorless technique. The manufacturer's technical documentation offers different support macros to be applied specifically in the motor control branch from the C2000 family of real-time control MCUs ${ }^{\mathrm{TM}}$ [9].

Control methodology: The control of an induction motor used is known in the literature as "sensorless control" and allows to bring the induction motor to a stable state through simple schemes fed by voltage, current making the estimation and control of the rotor speed [10].

The control developed is based on the principle of the loop shown in Figure 1 where the value of the rotor speed depends on a magnetic flux and speed estimators. The estimation of the stator magnetic flux based on the voltage model, the stator current based with its proportionality with the rotor speed by means of Clarke's transformations [11].

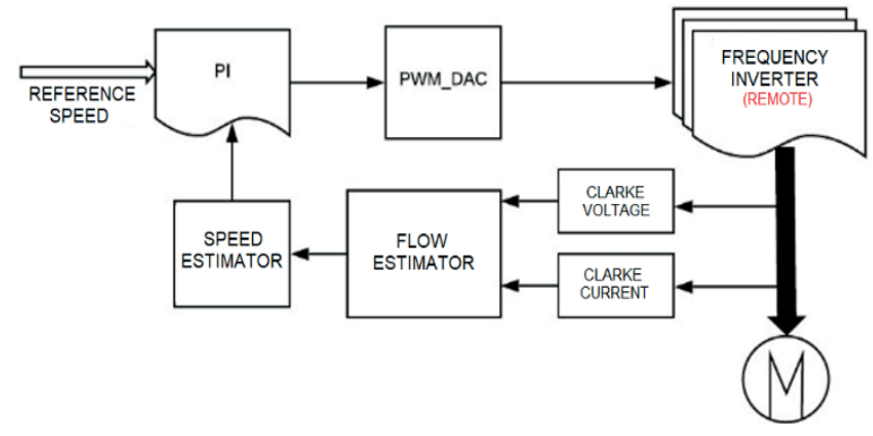

Figure 1. Scheme of the sensorless control proposed.

The sensorless control proposed is the scaling which is based in such a way that, when the frequency is reduced, the voltage is reduced proportionally, that is, with a constant Voltage/ Frequency or simply V/Hz command law [10]-[12].

Clarke's Transformation: For the development of the control, Clarke's transform converts the time domain components of a three-phase system, Figure 2, into two components of an orthogonal stationary frame $(\alpha \beta)$ [13].

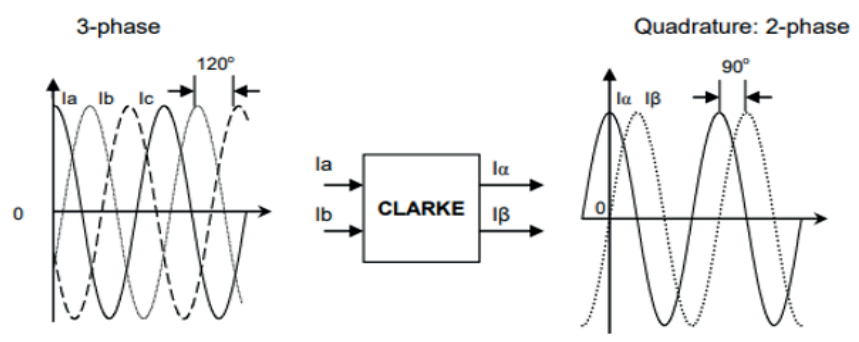

Figure 2. Clarke's Transformation [13].

Flow Estimator: The induction motor model can be expressed in the fixed reference frame $d-q$ by equations according to Figure 3 [14].

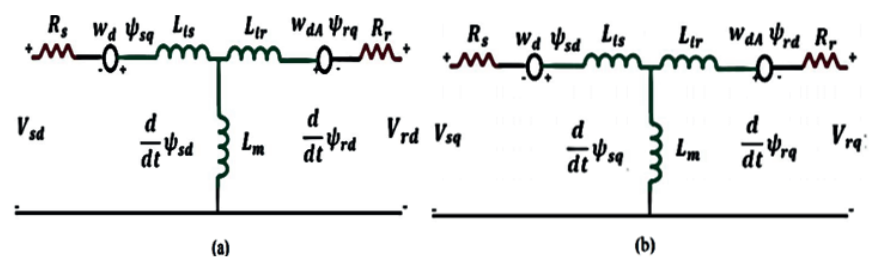

Figure 3. Induction motor equivalent circuit. (a) d reference frame. (b) q reference frame [14].

According to Figure 3, the equations in the d-q frame of reference can be obtained according [15]: 


$$
\begin{gathered}
V_{s d q}=R_{s} i_{s d q}+\frac{d}{d t} \Psi_{s d q}-j w_{g} \Psi_{s d q} \\
0=R_{r} i_{r d q}+\frac{d}{d t} \Psi_{r d q}-j\left(w_{g}-w_{r}\right) \Psi_{r d q} \\
\Psi_{s d q}=L_{s} i_{s d q}+L_{m} i_{r d q} \\
\Psi_{\mathrm{rdq}}=\mathrm{L}_{\mathrm{r}} \mathrm{i}_{\mathrm{rdq}}+\mathrm{L}_{\mathrm{m}} \mathrm{i}_{\mathrm{sdq}}
\end{gathered}
$$

According to the above is calculated in [15], the rotor flux linkages in the two d-q reference frames as shown below.

$$
\begin{aligned}
& \psi_{d r}^{s, v}=-\left(\frac{L_{s} L_{r}-L_{m}^{2}}{L_{m}}\right) i_{d s}^{s}+\frac{L_{r}}{L_{m}} \Psi_{d s}^{s, v} \\
& \psi_{q^{r}}^{s, v}=-\left(\frac{L_{s} L_{r}-L_{m}^{2}}{L_{m}}\right) i_{q s}^{s}+\frac{L_{r}}{L_{m}} \Psi_{q s}^{s, v}
\end{aligned}
$$

And the angle is calculated as:

$$
\theta_{\psi_{\tau}}=\tan ^{-1}\left(\frac{\psi_{\mathrm{qr}}^{\mathrm{s,y}}}{\psi_{\mathrm{dr}}^{\mathrm{s,v}}}\right)
$$

In this way the flux linkage was obtained with their respective angle as described is [15], necessary for the estimation of the rotational speed.

Speed estimator: The open-loop speed estimator is derived based on the mathematical equations of the induction motor in the stationary reference frame and the flux linkages along with the angle calculated above [16].

$$
\begin{aligned}
& 0=\mathrm{R}_{\mathrm{r}} \mathrm{i}_{\mathrm{dr}}^{\mathrm{s}}+\omega_{\mathrm{r}} \lambda_{\mathrm{qr}}^{\mathrm{s}}+\frac{\mathrm{d} \lambda_{\mathrm{dr}}^{\mathrm{s}}}{\mathrm{dt}} \\
& 0=\mathrm{R}_{\mathrm{r}} \mathrm{i}_{\mathrm{qr}}^{\mathrm{s}}-\omega_{\mathrm{r}} \lambda_{\mathrm{dr}}^{\mathrm{s}}+\frac{\mathrm{d} \lambda_{\mathrm{qr}}^{\mathrm{s}}}{\mathrm{dt}} \\
& \lambda_{\mathrm{dr}}^{\mathrm{s}}=\mathrm{L}_{\mathrm{r}} \mathrm{i}_{\mathrm{dr}}^{\mathrm{s}}+\mathrm{L}_{\mathrm{m}} \mathrm{i}_{\mathrm{ds}}^{\mathrm{s}} \\
& \lambda_{\mathrm{qr}}^{\mathrm{s}}=\mathrm{L}_{\mathrm{r}} \mathrm{i}_{\mathrm{qr}}^{\mathrm{s}}+\mathrm{L}_{\mathrm{m}} \mathrm{i}_{\mathrm{qs}}^{\mathrm{s}}
\end{aligned}
$$

According to the above is calculated in [15], the speed in the rotor by equation 8 .

$$
\begin{gathered}
\omega_{\mathrm{c}}=\frac{\mathrm{d} \theta_{\lambda_{r}}}{\mathrm{dt}} \\
\omega_{\mathrm{r}}=\omega_{\mathrm{c}}-\frac{1}{\left(\lambda_{\mathrm{r}}^{\mathrm{s}}\right)^{2}} \frac{\mathrm{L}_{\mathrm{m}}}{\tau_{\mathrm{r}}}\left(\lambda_{\mathrm{dr}}^{\mathrm{s}} \mathrm{i}_{\mathrm{qs}}^{\mathrm{s}}-\lambda_{\mathrm{qr}}^{\mathrm{s}} \mathrm{i}_{\mathrm{ds}}^{\mathrm{s}}\right)
\end{gathered}
$$

\section{Design of the main control algorithms of the system and description of the final adapted control element}

Frequency inverter: To control the plant in the proposed system adopted a frequency converter ABB ACS800-U1 [17], which is configured in remote mode and control scale the speed change according to the signal from the control system implemented in the DSP as shown in Figure 4 [18].

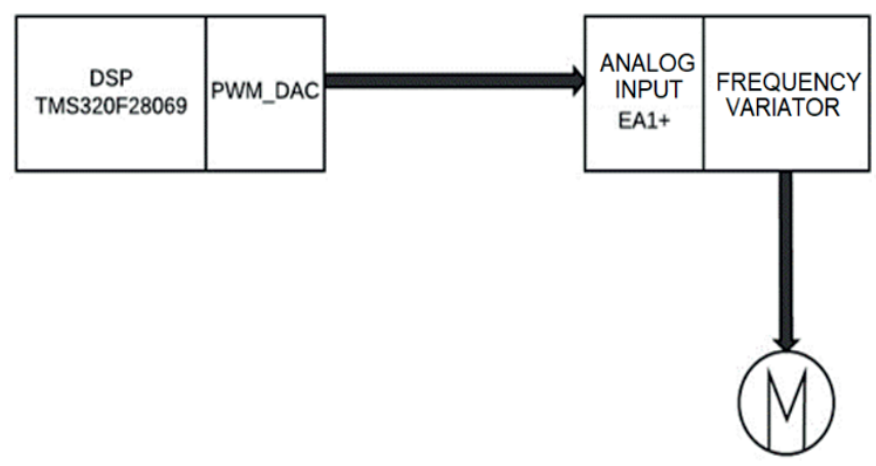

Figure 4. Frequency inverter diagram

The frequency inverter is controlled by an analog input which comes from a PWM_DAC output of the DSP, the voltage level at the input corresponds to an output frequency of the inverter therefore a speed. Figure 5 shows the coupling circuit.

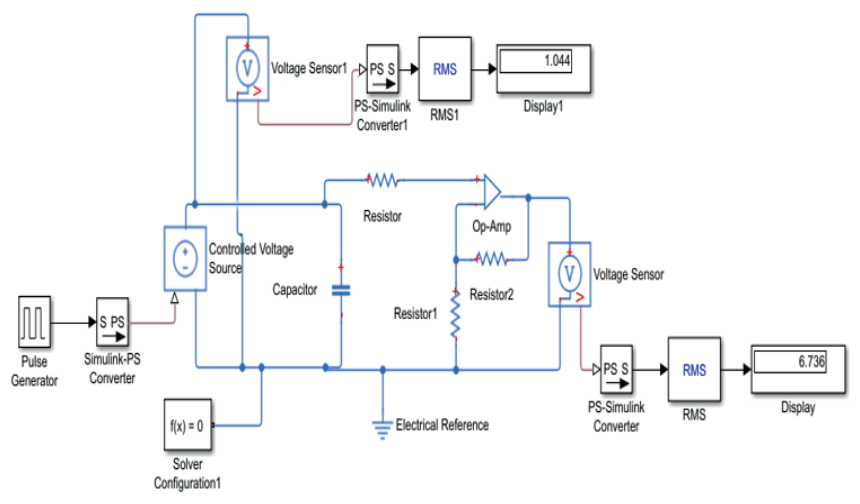

Figure 5. Signal Amplification Circuit PWM_DAC

Description of the main algorithm of the open-loop control system: The algorithm and code described was developed in the CODE COMPOSER STUDIO (CCS) programming environment with CCS language. Figure 6 shows the block diagram of the algorithm executed to generate each work cycle of the PWM module, with which the analog reference at the inverter input is controlled. 


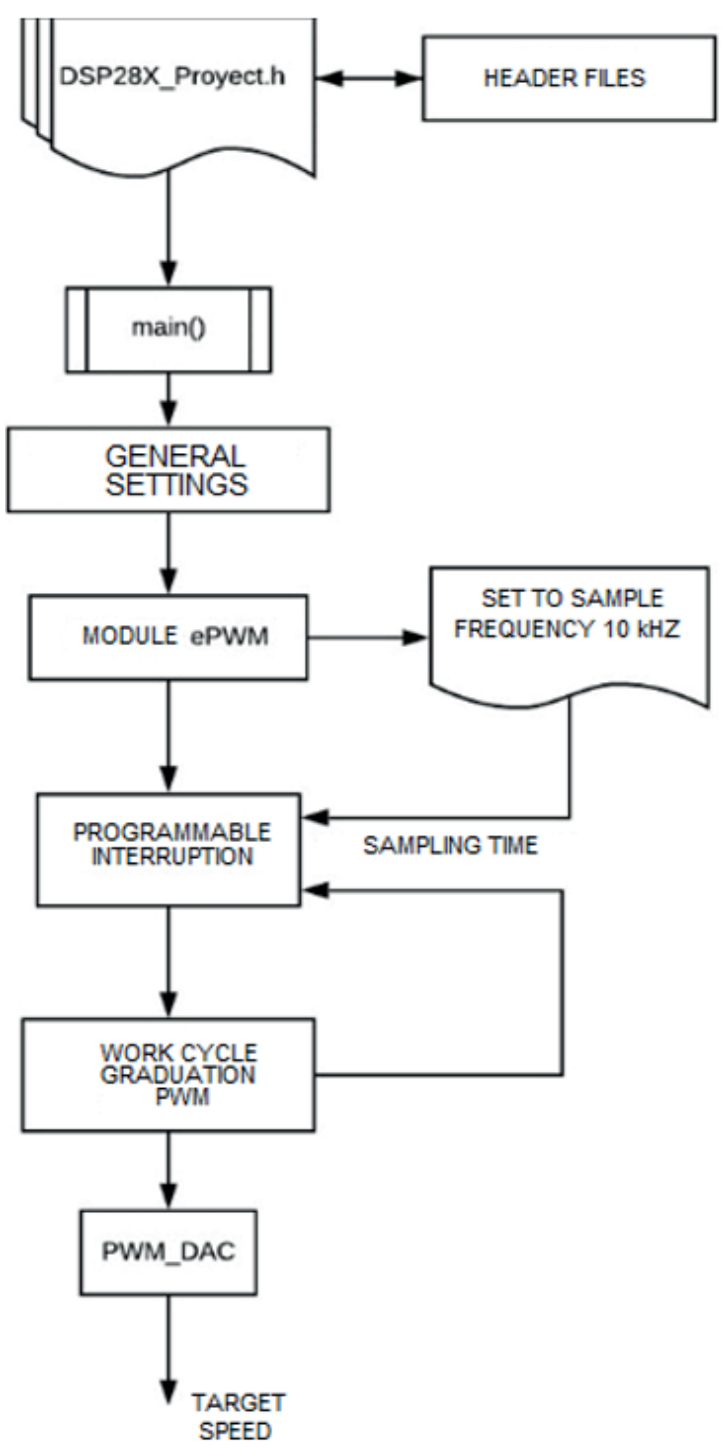

Figure 6. Block diagram of open-loop operation.

The algorithm and code described was developed in the CODE COMPOSER STUDIO programming environment with CCS language. Figure 6 presents the diagram of the algorithm executed to generate each work cycle of the PWM module with which the analog reference at the inverter input is controlled.

Implementation of the control technique:For the control, the voltage and current signals must be acquired, which are normalized into P.U. values. according to the base value of each one, then a digital filtering is done with a FIR filter to the voltage and current signals that feed the induction motor. Then Clarke transformations are applied to the filtered signals, to estimate the flux linkages angles at the flux estimation block. Thus, firstly determining the above, we proceed to estimate the motor speed in revolutions per minute (rpm) sending the signal to the PI controller, which gives a response according to the speed set point that changes the duty cycle of the physical output PWM_DAC of the DSP, thus closing the control loop [19].

A. Acquisition and filtering of voltage and current signals: In Figure 7, the algorithm implemented for the configuration of the ADCINAx as an analog input for reading current and voltage is described by means of a block diagram [19].

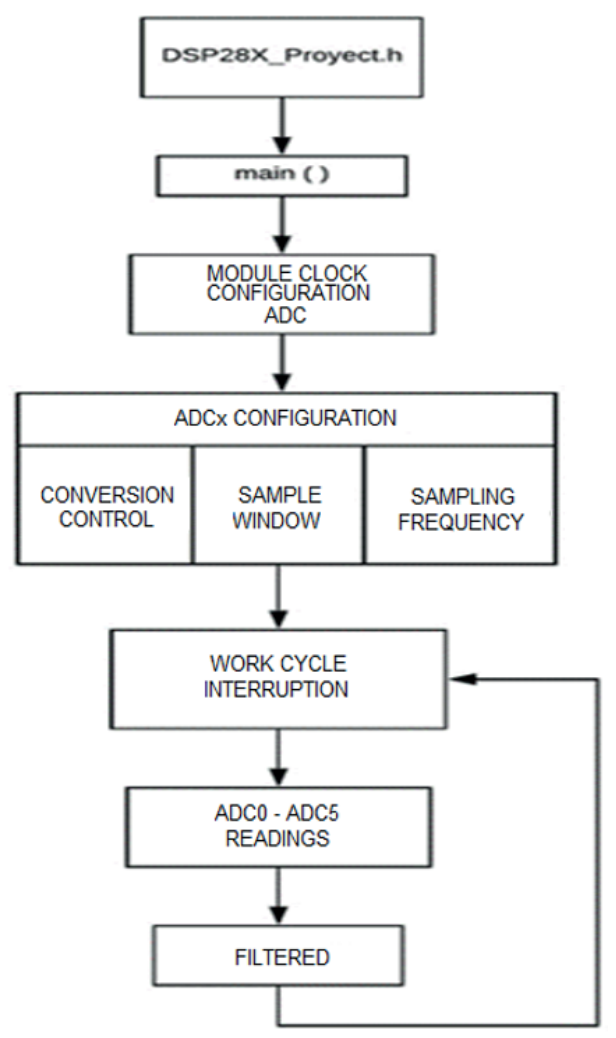

Figure 7. Acquisition algorithm.

The Finite Impulse Response (FIR) digital filter is based on obtaining the output exclusively from the current and previous inputs [20]. The FIR coefficients can be generated by the MATLAB filter design and analysis tool (FDATool), in which the type of filter is added which is low pass, the filter order which is set to 196 and the sampling frequency which is $10 \mathrm{KHz}$ with a pass frequency of 120 and cut-off frequency of $250 \mathrm{~Hz}$ figure 8 . 


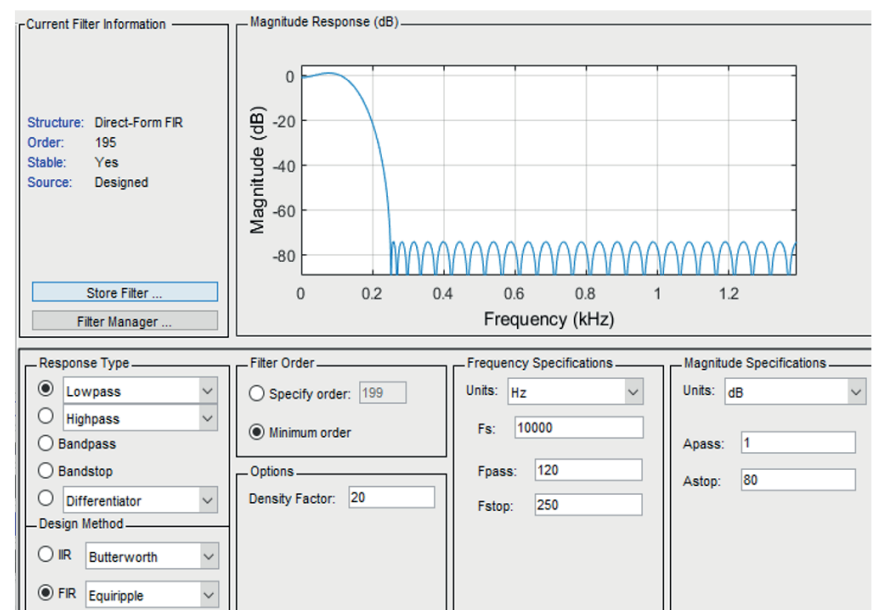

Figure 8. Coefficient calculation (FDATool).

B. Implementation of flow and speed estimator: After implementing the filter, Clarke's transformation to voltage and current is performed, and the algorithmic implementation of the flux estimator is based on what is described in [13]. Figure 9 shows a block diagram of the flux estimator where the above equations are applied, but in their discrete form.

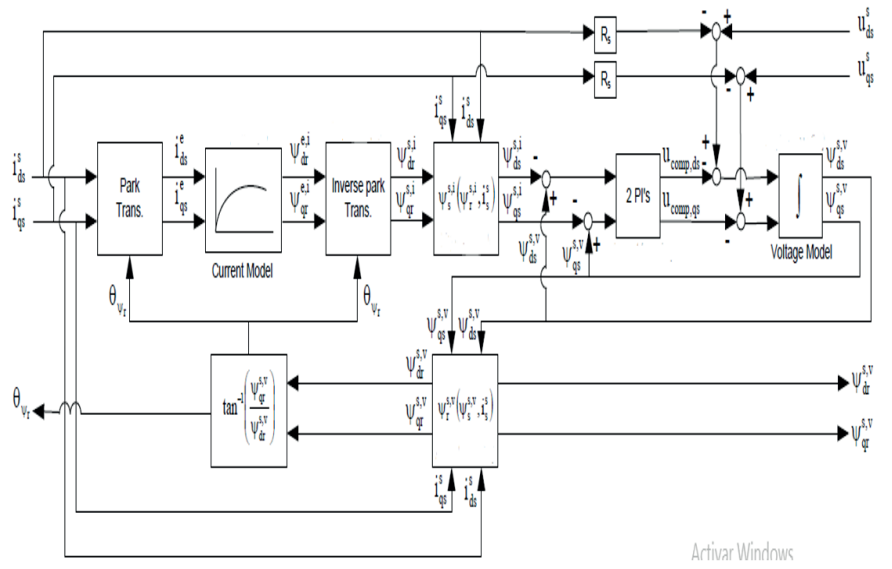

Figure 9. Flow Estimator Algorithm [13].

For the implementation of the speed estimator at the algorithm level it is done from the equations described in [13], but in a discrete way.

$$
\begin{gathered}
\omega_{\mathrm{r}, \mathrm{pu}}=\omega_{\mathrm{c}, \mathrm{pu}}-\mathrm{K}_{\mathrm{l}}\left(\frac{\lambda_{\mathrm{dr}, \mathrm{pu}}^{\mathrm{s}} \mathrm{i}_{\mathrm{qs}, \mathrm{pu}}^{\mathrm{s}}-\lambda_{\mathrm{qr}, \mathrm{pu}}^{\mathrm{s}} \mathrm{i}_{\mathrm{ds}, \mathrm{pu}}^{\mathrm{s}}}{\left(\lambda_{\mathrm{r}, \mathrm{pu}}^{\mathrm{s}}\right)^{2}}\right) \quad \mathrm{pu} \\
\omega_{\mathrm{c}, \mathrm{pu}}(\mathrm{k})=\frac{1}{\mathrm{f}_{\mathrm{b}}}\left(\frac{\theta_{\lambda_{\mathrm{r}} \mathrm{pu}}(\mathrm{k})-\theta_{\lambda_{\mathrm{r}, \mathrm{pu}}}(\mathrm{k}-1)}{\mathrm{T}}\right) \quad \mathrm{pu}
\end{gathered}
$$

\section{Results and analysis}

\section{Functionality and validation tests}

Figure 10 shows the assembly carried out where you can see the frequency converter used.

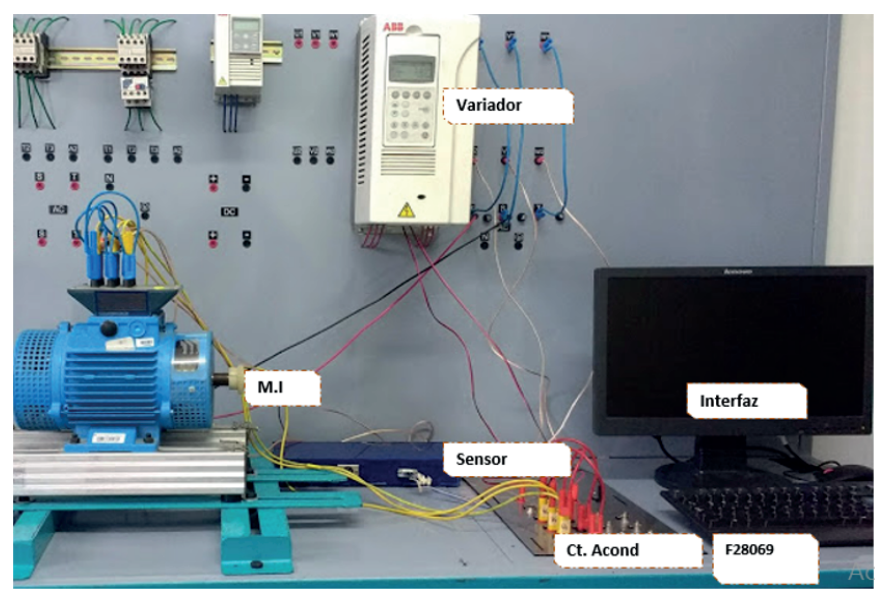

Figure 10. Mounted system (experimental setup).

A. Voltage and current signals obtained: Figure 11 shows the three-phase voltage and current signals obtained from the power input of the induction motor, where the voltage signal delivered by the frequency converter is highlighted.

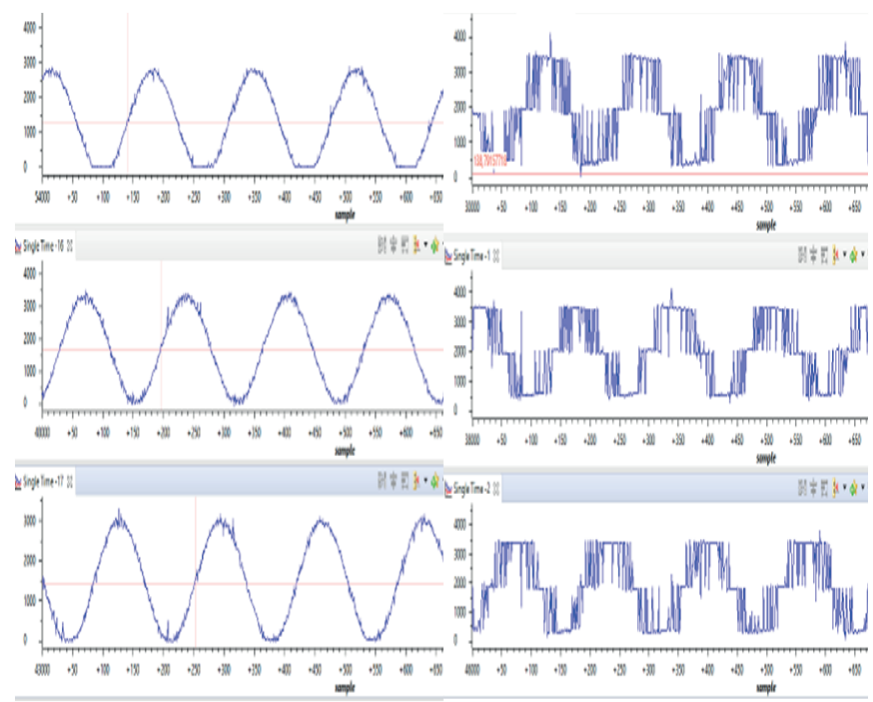

Figure 11. a) Electrical current acquired signal. b) Voltage acquired signal.

The signals are displayed with the help of the CODE COMPOSER STUDIO software in your graphic environment. Figure 12 shows the digitally filtered signal with the proposed FIR filter 

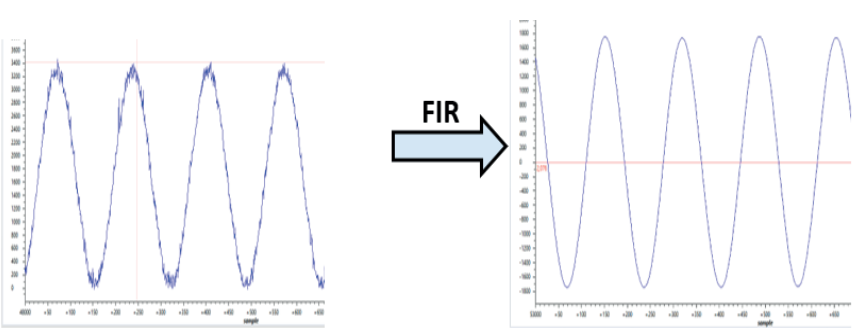

a)
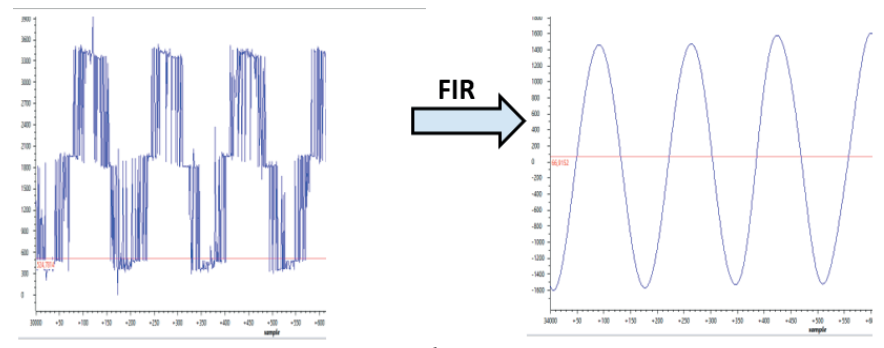

b)

Figure 12. a) Current filtered signal. b) Voltage filtered signal.

B. Validation of flow and velocity estimation: TTo make the speed estimation it is necessary to obtain the electrical parameters of the induction motor obtained with the help of measuring instruments such as Fluke 123 and Fluke 434 which is in accordance with the IEC 61000-4-7 standard. The results are:

$$
\begin{gathered}
R r=13.62 \Omega \\
R s=7 \Omega \\
L r=0.0334 H \\
L s=0.0334 H \\
L m=0.5791 H
\end{gathered}
$$

Figure 13 presents Clarke's transformations of current and voltage respectively.
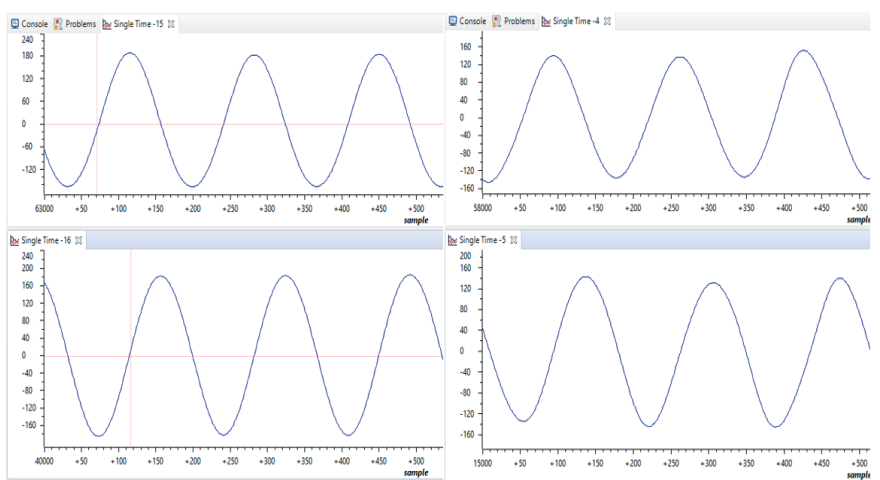

Figure 13. Electrical current and voltage Clarke transformation.

The in Figure 14 presents the flux angle of the induction machine which varies from 0 to $2 *$ pi, found with the flux estimation block [13].

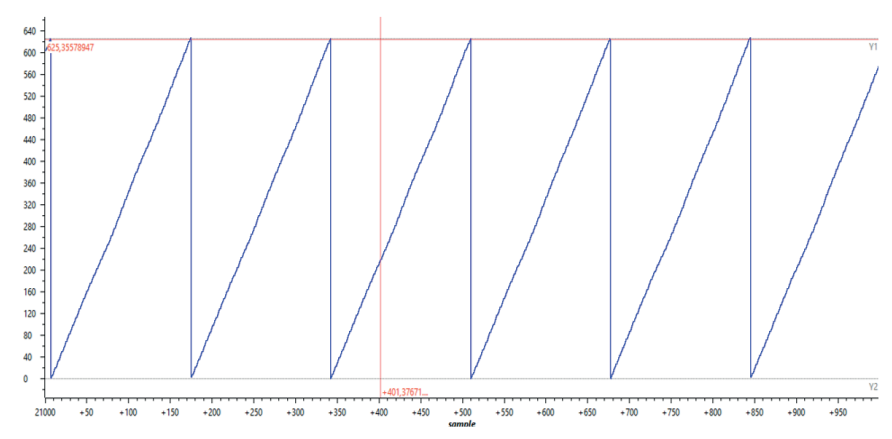

Figure 14. Magnetic flux angle.

Next you can see the flow of the rotor in the stationary axis $q$ - $d$ which is the output of the estimator used [13].

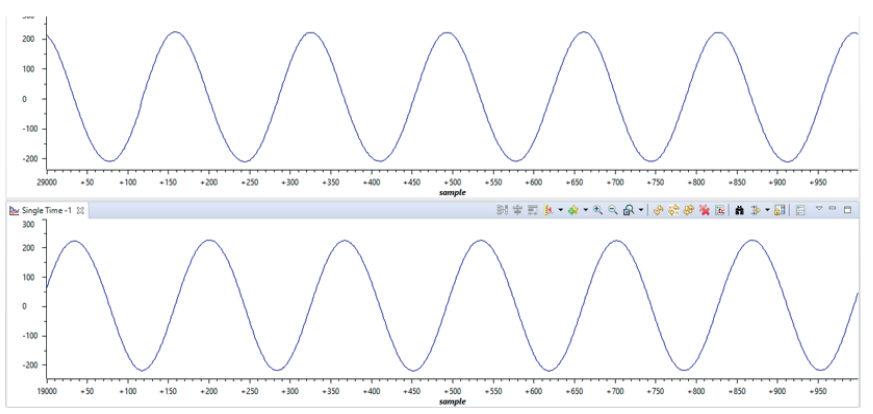

Figure 15. Estimated rotor flux $d$-q reference frame.

Figure 16 validates the correct operation of the open-loop speed estimation since changes are made in the work cycle of PWM_DAC and therefore the speed from 900 rpm to $2700 \mathrm{rpm}$. 


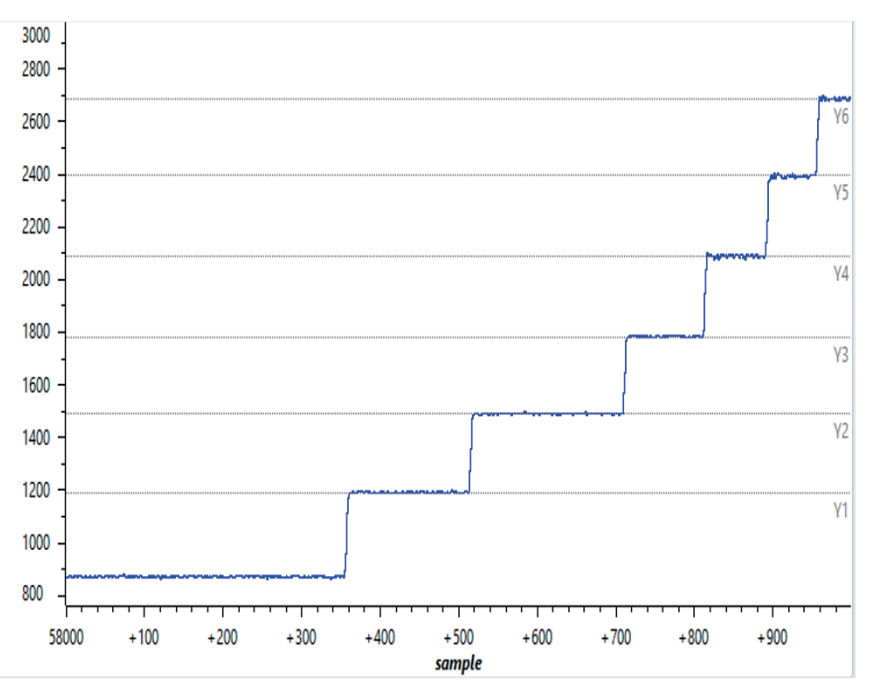

Figure 16. System response to speed changes.
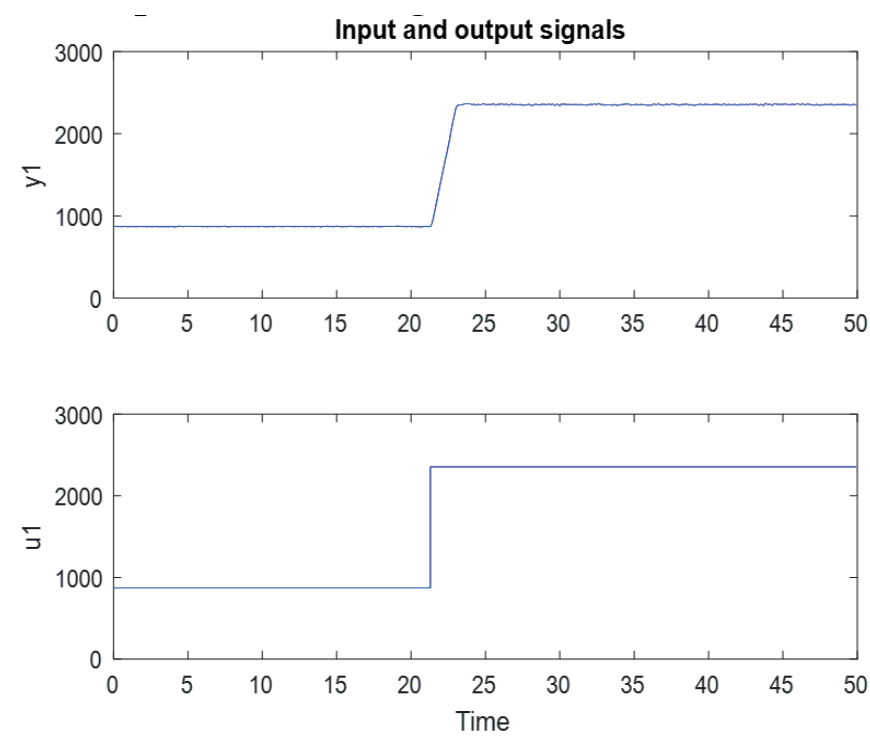

$\frac{0.5897 * S^{2}+0.66083 * S+10.053}{S^{3}+4.0456 * S^{2}+9.9217 * S+10.0521}$

Figure 17. System modeling.

A PI controller is simulated and tuned in Matlab according to the plant model obtained previously in figure 18 presented.

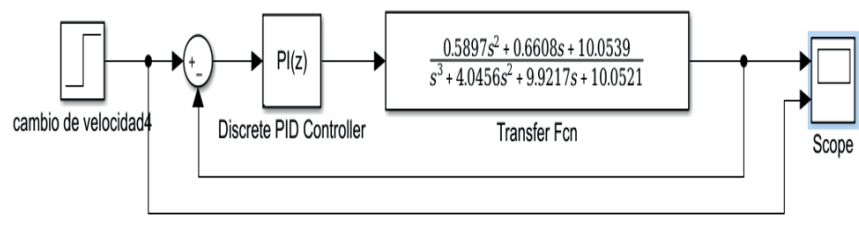

Figure 18. Simulation of the problem.

\section{Closed-loop speed control system monitoring:} Through the monitoring interface proposed, a target speed of $1800 \mathrm{Rpm}$ is established. It is worth noting that this target speed is the real speed of the engine validated with the digital tachometer. Figure 19 shows $\boldsymbol{y} \boldsymbol{k}$.
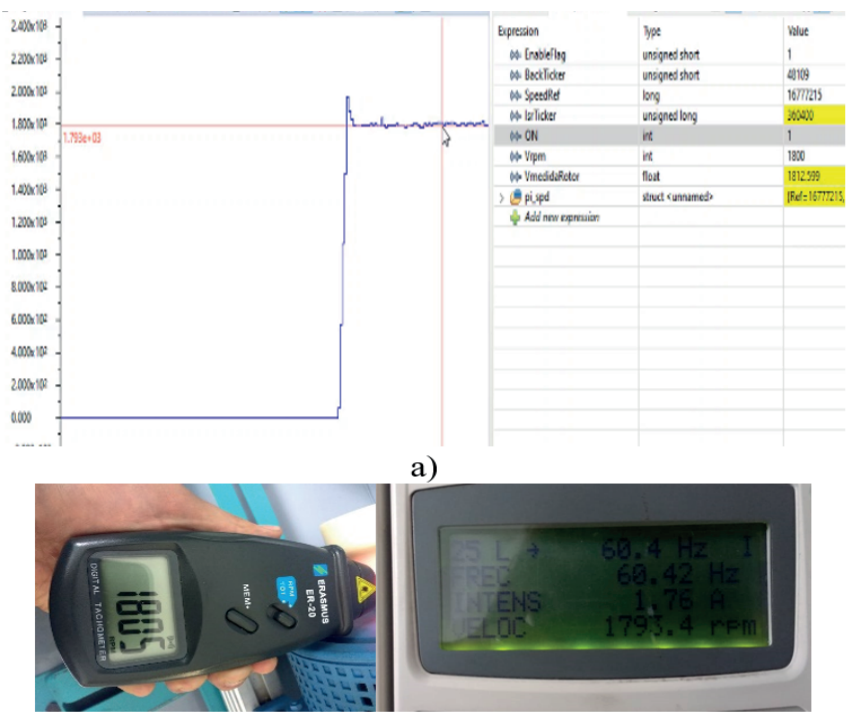

b)

Figure 20. a) Speed change. b) Actual measured speed

Figure 21 changes the set point from $1800 \mathrm{rpm}$ to 1100 rpm in order to visualize the speed change from one point to another, thus presenting the controller directly with a speed change.

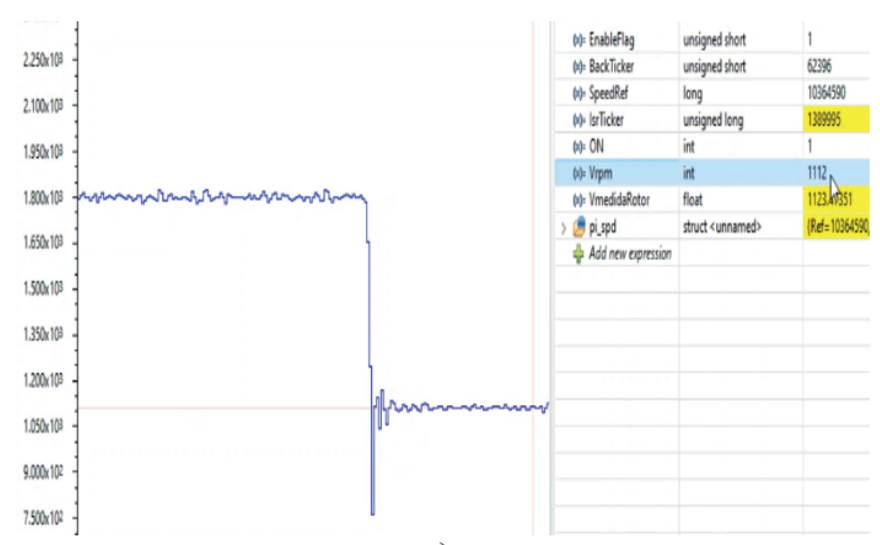

a)

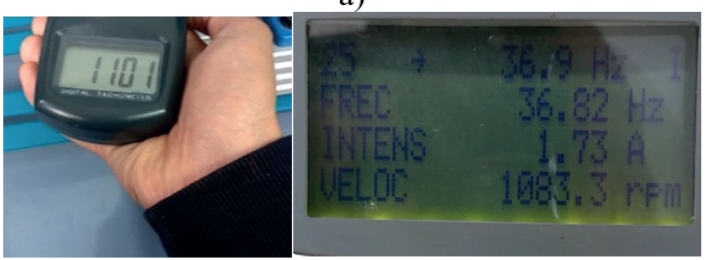

b) 
Finally, a change is made to the speed above the nominal one to completely validate the system implemented at $2150 \mathrm{rpm}$ as can be seen in Figure 22, such approach by the interface can also be used in the educational context [23]- [26].

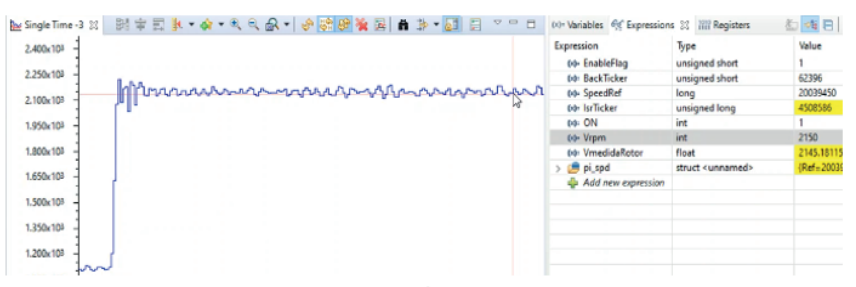

a)

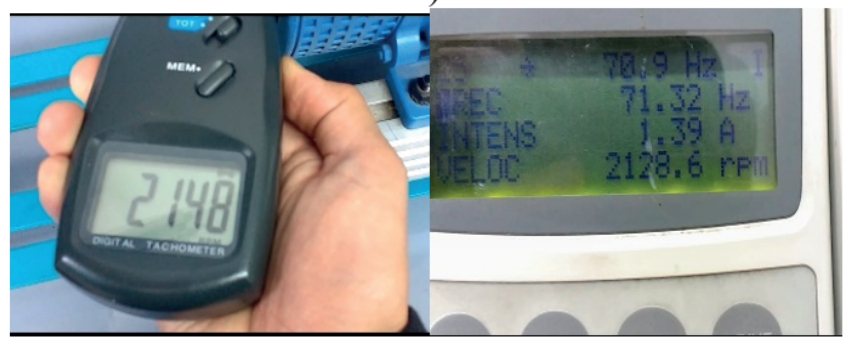

b)

Figure 22. a) Speed change. b) Actual measured speed.

\section{Conclusions}

The designed system with the use of the tools provided by Texas Instruments are suitable for signal filtering and flux estimation of the electric machine. Becoming a vital process in the success of the proposed sensorless control. However, the errors in the estimation at low frequencies must be taking into account.

The development of the sensorless control proposed involves a high level of accuracy in the acquisition of the signals, their correct sequence of phases, the appropriate transformation to values per unit with a system of congruent bases. Since the adequate treatment of the sensed signals becomes a fundamental issue of the operation of the proposed algorithms.

The proposed PI controller, and later developed in CCS language, presented an appropriate and advantageous behavior. Since, having 2 control loops only reduces the elapse time in terms of performing times and does not overload the program memory. Thus, optimizing and adapting to other proposed stages within the same board.

The TMS320F28060 device, based on bit field structures, allowed to adopt the algorithms in a suitable way and to have a sensorless controller with an excellent behavior and a low cost.

The accomplishment of several $R \& D$ projects within the University of Pamplona with the accompany of several organizations [21]- [27], has allowed the development of this research. We consider that this work will contribute to reducing the gap between the technological development and foreign dependence, in terms of develop and implementation of variable speed drives (VSD) and multilevel converters (MLC). We hope that with the progress of the R\&D projects will allow to obtain autochthonous prototypes that can be apply directly to the local and national industry.

\section{References}

[1] Texas Instruments Incorporated, "C2000TM PiccoloTM 32-bit MCU Family," Dallas, Texas, 2010.

[2] A. Álzate, M. Yarce, and G. Valencia, "Control de velocidad mediante relación voltaje- frecuencia," Sci. Tech., no. 49, pp. 19-24, 2011.

[3] Texas Instruments Incorporated, "TMS320C28x CPU and Instruction Set Reference Guide," 2015.

[4] J. Villalón and F. Salas Gómez, "Modelado, simulación y control de convertidores en cascada," Sevilla, 2017.

[5] K. Preethi, G. Anil, and E. Vani, "Speed Control of Induction Motor Using Eleven Levels Multilevel Inverter," circuit.International J. Sci. Mod. Eng., no. 5, pp. 15-20, 2013.

[6] Texas Instruments Incorporated, "TMS320F2806x PiccoloTM Microcontrollers," Dallas, texas, 2018.

[7].Niño, AB (2018). “Microturbina Peltón, una solución real de energía para zonas no interconectadas (ZNI) ". Revista Tecnologías de Avanzada, ISSN: 1692-7257, 2018. 
[8] Texas Instruments Incorporated, "User's Guide LAUNCHXL-F28069M Overview," Dallas, Texas, 2019.

[9] J. Pérez and J. Barrero, "Diseño de un sistema empotrado basado en DSP C2000 de Texas Instruments para control de armario de potencia de 12 fases," Sevilla, 2015.

[10] B. Larimore, "HVAC Dual-AC Motor Control with Active PFC Implementation Using Piccolo TM MCUs," 2010.

[11] A. Pardo and J. L. Díaz, Aplicaciones de los convertidores de frecuencia estrategias pwm en el control. Colombia: 2004, 2004.

[12] Peñaranda and A. E. Caicedo, "Sensorless control of an induction motor with common source multilevel converter," WSEAS Trans. POWER Syst., pp. 1-2, 2018.

[13] B. Akin and N. Garg, "Scalar (V/f) Control of 3-Phase Induction Motors," no. July, pp. 1-25, 2013.

[14] T. Instruments, "Digital Motor Control Software Library: Target Independent Math Blocks,” 2013.

[15] Velásquez Pérez T, Espinel Blanco E, Guerrero Gómez G. "Estrategias pedagógicas en el aula de clase". Revista Tecnologías de Avanzada, ISSN: 1692-7257, 2016.

[16] H. F. Rashag, S. P. Koh, A. N. Abdalla, N. M. L. Tan, and K. H. Chong, "Modified Direct torque control using algorithm control of stator flux estimation and space vector modulation based on fuzzy logic control for achieving high performance from induction motors," J. Power Electron., vol. 13, no. 3, pp. 369-380, 2013.

[17] B. Akin and M. Bhardwaj, "Sensorless Field Oriented Control of 3-Phase Induction Motors," Appl. note, p. 43, 2010.
[18] C. Lascu, I. Boldea, and F. Blaabjerg, "Direct torque control of sensorless induction motor drives: A sliding-mode approach," IEEE Trans. Ind. Appl., vol. 40, no. 2, pp. 582-590, 2004.

[19] ABB, "Manual de firmware Programa de control estándar 7.x del ACS800.” 2011.

[20] J. Diaz Plata, “método para aprender a utilizar el variador de frecuencia abb acs800-u1 de forma rápida y sencilla a través de diferentes prácticas de laboratorio," universidad de pamplona, 2019.

[21] Texas Instruments Incorporated, "TMS320x2806x Piccolo Technical Reference Manual.” Dallas, Texas, 2017.

[22] A. . S. M. Martínez, L. Gómez, "Diseño De Filtros Fir," Esc. Técnica Super. d'Eng. Dep. d'Enginyeria Electrónica, pp. 1-26, 2010.

[23] Plaza J, Ruiz M, Rosero C, Zapata L. Formación en competencias específicas para la industria del software colombiano. Experiencias del uso del aprendizaje basado en proyectos". Revista Tecnologías de Avanzada, ISSN: 1692-7257, 2017.

[24] García-León, RA, Solano, EF, Acevedo A. "Caracterización térmica de mezclas de arcillas utilizadas en la fabricación de productos de mampostería para la construcción". Revista Tecnologías de Avanzada, ISSN: 1692-7257, 2018.

[25] Hernández Tolosa C, Contreras Eugenio B, Torres Sánchez C. "Desarrollo de libros electrónicos: "taller pedagógico". Revista Tecnologías de Avanzada, ISSN: 1692-7257, 2016.

[26] A. Bohórquez-Niño, "Microturbina pelton, una solución real de energía para zonas no interconectadas (ZNI)", Revista Colombiana de Tecnologías de Avanzadas, vol. 1, no. 31, pp. 72- 
$76,2018$.

[27] Márquez, L, Lara, YA, Ángulo, F “Prototipo de control de acceso a aulas y registro automático de asistencia". Revista Tecnologías de Avanzada, ISSN: 1692-7257, 2017. 